\title{
PROFESI BIMBINGAN DAN KONSELING DI ERA DISRUPSI: PELUANG DAN TANTANGAN
}

\author{
Oleh Dr. Hartono, M.Si. \\ Dosen Program Studi Bimbingan dan Konseling \\ Universitas PGRI Adi Buana Surabaya \\ E-mail: hartono@unipasby.ac.id dan hartono140@yahoo.com
}

\begin{abstract}
Abstrak
Bimbingan dan konseling merupakan profesi yang inovatif dan kolaboratif di era disrupsi. Kontribusi profesi bimbingan dan konseling terhadap perkembangan IPTEKS berlangsung se-arah jarum jam yang berputar terus tanpa berhenti, sehingga secara konsisten, eksistensi profesi bimbingan dan konseling selalu dibutuhkan dan dipercaya oleh masyarakat global sebagai pengguna profesi. Kesadaran dan keterlibatan para praktisi dan akademisi profesi bimbingan dan konseling dalam melakukan penelitian dan pengembangan terpelihara dan tertata dalam melakukan berbagai inovasi yang sesuai dengan kebutuhan peserta didik sebagai konseli.
\end{abstract}

Kata kunci: bimbingan dan konseling, era disrupsi.

\section{PENDAHULUAN}

Profesi bimbingan dan konseling yang awalnya berupa gerakan bimbingan (guidance movement) yang telah berlangsung pada awal tahun 1900-an di Amerika Serikat yang dipelopori oleh seorang tokoh besar yang bernama Frank Parson, dalam perkembangannya di Indonesia sebagai bagian integral pada praksis pendidikan formal sejak diberlakukannya kurikulum tahun 1975 (Buku III C Pedoman Bimbingan dan Penyuluhan). Sampai saat ini, perkembangan profesi bimbingan dan konseling tidak hanya berada pada tataran teoritis (konseptual), namun meluas menjadi tataran praksis (praktik) yang diperkuat dengan diberlakukannya Undang-Undang RI Nomor 14 Tahun 2005 tentang Guru dan Dosen. Menurut Undang-Undang tersebut, guru (termasuk guru bimbingan dan konseling) sebagai profesi pendidik, sehingga pada mereka diamanati sejumlah persyaratan, di antaranya; memiliki kualifikasi akademik S1 atau Diploma IV dalam bidangnya, menguasai kompetensi, memiliki sertifikat pendidik, mampu mewujudkan tujuan pendidikan nasional, dan profesi sebagai panggilan jiwa.

Dalam kehidupan bermasyarakat, profesi merupakan mata pencaharian yang dibutuhkan oleh pengampu dan pengguna. Pada pihak pengampu yaitu guru bimbingan dan konseling dengan memberikan pelayanan bimbingan dan konseling yang memandirikan peserta didik sebagai konseli, mereka memperoleh kompensasi profesi berupa gaji pokok, tunjangan profesi, dan pendapatan lain 
yang sah menurut peraturan perundang-undangan. Di pihak pengguna yaitu peserta didik sebagai konseli, dengan mendapatkan pelayanan bimbingan dan konseling yang dibutuhkan, mereka memperoleh manfaat layanan profesi yaitu perubahan perilaku ke arah lebih baik, lebih maju dalam menunjang proses perkembangannya menuju menjadi orang dewasa, yang sehat, sejahtera, dan bermartabat.

Perkembangan profesi bimbingan dan konseling telah melewati beberapa zaman/era, dari era konvensional/tradisional sampai pada era modern yang berimplikasi pada kebutuhan dan pola hidup masyarakat. Di dalam era modern yang bercirikan penggunaan teknologi informasi (IT) pada berbagai aktivitas kehidupan, semua profesi termasuk profesi bimbingan dan konseling sebagai pihak yang kena dampaknya, baik positif yang menguntungkan maupun negatif yang merugikan. Dampak negatif yang berbahaya bagi profesi bimbingan dan konseling adalah bisa mati, karena tidak lagi dibutuhkan oleh peserta didik/konseli, dan bisa teralihkan ke profesi psikologi di lembaga pendidikan formal. Untuk mengantisipasi agar dampak negatif tersebut tidak terjadi, semua warga profesi bimbingan dan konseling yang tergabung pada organisasi profesi Asosiasi Bimbingan dan Konseling Indonesia (ABKIN) harus melakukan upaya cerdas dalam mengembangkan profesi bimbingan dan konseling di tanah air.

\section{HAKIKAT ERA DISRUPSI}

Menurut KBBI daring, disrupsi artinya hal tercabut dari akarnya. Tercabut dari akarnya berarti terlepas dari akarnya atau bebas tidak terbatas, bisa kemanamana. Era disrupsi adalah suatu zaman yang diwarnai oleh perilaku inovasi, dan perubahan yang sangat cepat yang berdampak pada organisasi dan kehidupan masyarakat luas. Pada era ini, suatu badan, lembaga, organisasi, perkumpulan, atau apa namanya yang berbentuk aliansi akan segera mati, bila tidak melakukan perubahan sistem, pola, strategi, cara, metode yang sesuai dengan perkembangan IPTEKS dan kebutuhan masyarakat global. Di pihak lain, kebutuhan masyarakat global berjalan se-arah jarum jam dengan perkembangan IPTEKS. Dengan demikian, hakikat era disrupsi adalah suatu zaman yang penuh dengan inovasi yang disertai perubahan yang sangat cepat, yang berdampak positif dan negatif dalam kehidupan masyarakat. Dalam era ini, suatu organisasi yang kreatif dan inovasi dapat mematikan pihak yang bersifat konvensional.

\section{PERMASALAHAN PROFESI BIMBINGAN DAN KONSELING}

Sejumlah profesi di era disrupsi yaitu era bebas yang ditandai dengan adanya perubahan yang cepat sekali, akan, sedang, dan telah kena dampak negatif, bila tidak mampu mengatasi permasalahan yang sedang dihadapi oleh profesi tersebut, tak terkecuali profesi bimbingan dan konseling. Beberapa permasalahan yang dihadapi profesi bimbingan dan konseling di Indonesia dapat 
dirumuskan, antara lain: (1) belum semua guru bimbingan dan konseling lulusan program studi S1 bimbingan dan konseling; (2) adanya anggapan tugas guru bimbingan dan konseling bisa digantikan oleh guru apa saja; (3) adanya anggapan bahwa layanan bimbingan dan konseling di sekolah, tidak penting, yang penting pembelajaran; (4) rasio/nisbah guru bimbingan dan konseling di sekolah dengan siswa 1 : 150, belum terpenuhi; (5) fasilitas pelayanan bimbingan dan konseling di sekolah sebagian besar belum mencukupi; (6) belum semua LPTK penghasil guru bimbingan dan konseling, kualitasnya memadai; dan (7) belum membudaya jiwa profesi; serta masih ada lagi permasalahan yang lain.

Sejumlah permasalahan yang dihadapi oleh profesi bimbingan dan konseling di atas, membutuhkan pencermatan, analisis, dan sintesis yang cerdas berdasarkan fakta di lapangan. Kontribusi ABKIN sebagai organisasai profesi bimbingan dan konseling sangat dibutuhkan dalam mengawal, membina, dan mengembangkan kualitas pelayanan bimbingan dan konseling, melalui berbagai kegiatan ilmiah (seminar, workshop, pelatihan, pendampingan, penelitian, dan kegiatan lain yang inovatif).

\section{JATI DIRI PROFESI BIMBINGAN DAN KONSELING}

Permendiknas RI Nomor 27 tahun 2008 tentang standar kualifikasi akademik dan standar kompetensi konselor sampai saat ini diacu sebagai standar kompetensi guru bimbingan dan konseling. Dalam berbagai kegiatan kedinasan seperti UKG bagi guru bimbingan dan konseling, PLPG bagi guru bimbingan dan konseling, serta kegiatan pengembangan profesi guru yang disebut PKB (pengembangan keprofesian berkelanjutan) bagi guru bimbingan dan konseling yang sedang dan telah dilakukan, menggunakan permendiknas tersebut sebagai acuan dasar dalam menyusun program.

Guru bimbingan dan konseling identiknya sebagai konselor diamanati sebagai pendidik profesional yang berkualifikasi sarjana dalam bidang bimbingan dan konseling. Menurut Permendikbud Nomor 111 tahun 2014 tentang bimbingan dan konseling pada pendidikan dasar dan pendidikan menengah, guru bimbingan dan konseling berkualifikasi sebagai pendidik profesional, lulusan S1 bimbingan dan konseling, dan menguasai kompetensi dalam bidang bimbingan dan konseling. Dengan demikian jati diri profesi bimbingan dan konseling adalah pendidik profesional yang berkompeten dalam bidang bimbingan dan konseling, sehingga mampu memberikan pelayanan bimbingan dan konseling yang memandirikan peserta didik sebagai konseli. Ciri peserta didik yang mandiri dalam berbagai aktivitas, adalah (1) percaya diri, (2) bertanggung jawab, (3) kreatif dan inovatif, (4) mampu mengarahkan diri, dan (4) melakukan sendiri tanpa bantuan orang lain (Hartono, 2016). 


\section{MENJADIKAN PROFESI BIMBINGAN DAN KONSELING SEBAGAI PROFESI YANG BERMARTABAT}

Ada tiga kriteria yang bisa menunjukkan profesi bimbingan dan konseling sebagai profesi yang bermartabat, yaitu pengampunya: (1) menguasai ilmu bimbingan dan konseling yang dibangun dari ilmu psikologi, antropologi, sosiologi, dan pedagogi; (2) menguasai kompetensi bimbingan dan konseling; dan (3) dibutuhkan dan dipercaya masyarakat. Ketiga kriteria tersebut akan diuraikan sebagai berikut.

Menguasai ilmu bimbingan dan konseling. Pada hakikatnya pelayanan bimbingan dan konseling merupakan praksis dari psikologi, antropologi, sosiologi, dan pedagogi. Guru bimbingan dan konseling sebagai pendidik profesional, lazimnya menguasai keempat ilmu tersebut yang berperan mendasari pembentukan kompetensi bimbingan dan konseling.

Menguasai kompetensi bimbingan dan konseling. Kompetensi bimbingan dan konseling terumuskan pada Permendiknas RI Nomor 27 tahun 2008 tentang standar kualifikasi akademik dan standar kompetensi konselor. Standar kompetensi konselor yang harus dikuasi oleh guru bimbingan dan konseling, terdiri dari 17 butir, yaitu: (1) menguasai teori dan praksis pendidikan yang terdiri dari tiga sub butir; (2) mengaplikasikan perkembangan fisiologis dan psikologis serta perilaku konseli, yang terdiri dari lima sub butir; (3) menguasai esensi pelayanan bimbingan dan konseling dalam jalur, jenis, dan jenjang satuan pendidikan, yang terdiri dari tiga sub butir; (4) beriman dan bertakwa kepada Tuhan YME, yang terdiri dari tiga sub butir; (5) menghargai dan menjujung tinggi nilai-nilai kemanusiaan, individualitas dan kebebasan memilih, yang terdiri dari enam sub butir; (6) menunjukkan integritas dan stabilitas kepribadian yang kuat, yang terdiri dari empat sub butir; (7) menampilkan kinerja berkualitas tinggi, yang terdiri dari empat sub butir; (8) mengaplikasikan kolaborasi intern di tempat bekerja, yang terdiri dari tiga sub butir; (9) berperan dalam organisasi dan kegiatan profesi bimbingan dan konseling, yang terdiri dari tiga sub butir; (10) mengimplementasikan kolaborasi antar profesi, yang terdiri dari empat butir; (11) menguasai konsep dan praksis asesmen untuk memahami kondisi, kebutuhan, dan masalah konseli, yang terdiri dari sembilan sub butir; (12) menguasai kerangka teoritis dan praksis bimbingan dan konseling, yang terdiri dari enam sub butir; (13) merancang program bimbingan dan konseling, yang terdiri dari empat sub butir; (14) mengimplementasikan program bimbingan dan konseling yang komprehensif, yang terdiri dari empat sub butir; (15) menilai proses dan hasil kegiatan bimbingan dan konseling, yang terdiri dari empat sub butir; (16) memiliki kesadaran dan komitmen terhadap etika professional, yang terdiri dari tujuh sub butir; dan (17) menguasai konsep dan praksis penelitian bimbingan dan konseling, yang terdiri dari empat sub butir. 
Dibutuhkan dan dipercaya masyarakat. Semua profesi yang bisa bertahan hidup di era disrupsi adalah profesi yang dibutuhkan dan dipercaya masyarakat sebagai pengguna, sedangkan profesi yang tidak dibutuhkan dan juga tidak dipercaya masyarakat, maka profesi tersebut akan mati. Untuk dapat mempertahankan bimbingan dan konseling sebagai profesi yang eksis dalam kehidupan masyarakat, diperlukan upaya dari pengampu profesi bimbingan dan konseling yaitu guru bimbingan dan konseling sebagai pendidik profesional, dan para akademisi bimbingan dan konseling di perguruan tinggi sebagai pendidik profesional dan ilmuwan yang tergabung dalam ABKIN untuk melakukan kolaborasi dalam meningkatkan mutu pelayanan bimbingan dan konseling, sehingga mampu bekerja sama secara positif dengan profesi lain dalam memberikan pelayanan yang bermutu kepada masyarakat global.

\section{PELUANG DAN TANTANGAN PROFESI BIMBINGAN DAN KONSELING DI ERA DISRUPSI}

Era disrupsi merupakan era atau zaman yang bisa menguntungkan profesi bimbingan dan konseling, bila mampu memanfaatkan peluang dan sekaligus menghadapi tantangan. Sejumlah tantangan yang dihadapi profesi bimbingan dan konseling perlu dieliminasi untuk diubah menjadi peluang yang harus direbut oleh keluarga besar ABKIN sebagai organisasi profesi bimbingan dan konseling. Peluang tersebut mencakup beberapa ranah, yaitu: (1) keilmuan, (2) organisasi ABKIN, (3) kerja sama, dan (4) birokrasi dan politik. Pada ranah keilmuan, praktisi dan akademisi bimbingan dan konseling selalu berupaya dan mampu menggali, memahami, mengembangkan, dan menerapkan ilmu bimbingan dan konseling dalam kehidupan bermasyarakat. Pada ranah organisasi ABKIN, praktisi dan akademisi bimbingan dan konseling selalu berupaya dan mampu membesarkan ABKIN sebagai organisasi profesi yang kredibel dan akuntabel, sehingga mampu mengawal dan meningkatkan mutu pelayanan bimbingan dan konseling kepada peserta didik pada jalur pendidikan formal. Pada ranah kerja sama, praktisi dan akademisi bimbingan dan konseling selalu berupaya dan mampu berkolaborasi dengan profesi lain yang saling menguntungkan. Pada ranah birokrasi dan politik, praktisi dan akademisi bimbingan dan konseling memiliki wakil sebagai tempat penyaluran aspirasi untuk membesarkan profesi bimbingan dan konseling. Keempat ranah tersebut merupakan bagian yang membentuk sistem yang kuat dan bermartabat.

\section{KESIMPULAN}

Bimbingan dan konseling merupakan profesi yang perlu dikembangkan secara terus menerus dan konsisten, baik dari aspek konten, strategi layanan, organisasi, kerja sama, dan aspek lain yang berpengaruh positif terhadap eksistensi dan jati diri. Untuk mewujudkan hal tersebut, diperlukan usaha keras yang bersinergi oleh para praktisi yaitu guru bimbingan dan konseling di sekolah, 
dan para akademisi yaitu dosen di perguruan tinggi yang tergabung dalam organisasi ABKIN sebagai organisasi profesi bidang bimbingan dan konseling.

Berbagai kegiatan profesi bimbingan dan konseling yang bernilai inovatif, harus ditingkatkan secara kuantitatif dan kualitatif di era disrupsi, sehingga profesi bimbingan dan konseling mampu eksis, dan mampu memberikan pelayanan yang memandirikan kepada peserta didik sebagai konseli. Pelayanan bimbingan dan konseling saat ini dan ke depan merupakan produk inovasi para pengampu dan akademisi bimbingan dan konseling yang sesuai dengan dinamika dan kebutuhan masyarakat global.

\section{DAFTAR PUSTAKA}

Hartono dan Boy Soedarmadji. 2014. Psikologi Konseling: Edisi Revisi. Jakarta: Kencana Prenada Media Group.

Hartono dan Boy Soedarmadji. 2018. The developmen of computer-based career guidance application program for senior high school students. Advances in Social Science, Education and Humanites Research, 172, 136-139. Tersedia di http://www.atlantis-press.com/proceedings/icei-17/25892911.

Hartono. 2016. Bimbingan Karier. Jakarta. Kencana Prenada Media Group.

Mayling Oey-Gardiner, dkk. 2017. Era Disrupsi: Peluang dan Tantangan Pendidikan Tinggi Indonesia. Jakarta: Akademi IImu Pegetahuan Indonesia.

Permendikbud RI Nomor 111 Tahun 2014 tentang Bimbingan dan Konseling pada Pendidikan Dasar dan Pendidikan Menengah.

Permendiknas RI Nomor 27 Tahun 2008 tentang Standar Kualifikasi Akademik dan Standar Kompetensi Konselor. 